\title{
Evolution of a milkshed and role of alternative milk collection centres in Egypt
}

\author{
Annabelle Daburon ${ }^{1, *}$, Mohamed Radwan ${ }^{2}$, Véronique Alary ${ }^{1,3}$, Ahmed $\mathrm{Ali}^{4}$, \\ Sherif Abdelghany ${ }^{5}$ and Karim Fouad ${ }^{6}$ \\ ${ }^{1}$ CIRAD, UMR SELMET, TA C-112/A, Campus international de Baillarguet, 34398 Montpellier Cedex 5, France \\ 2 Department of Animal Production, Faculty of Agriculture, Cairo University, Giza, Egypt \\ 3 ICARDA, BP 6299, Station Exp. INRA-Quich, rue Hafiane Cherkaoui, Agdal Rabat-Institutes, Rabat, Morocco \\ 4 Animal Production Research Institute, Animal Production System Research Department, Dokki, Giza, Egypt \\ ${ }^{5}$ Department of Animal Production, Faculty of Agriculture, Cairo University, Giza, Egypt \\ ${ }^{6}$ ICARDA, 15 G. Radwan Ibn El-Tabib Street, Giza, Egypt
}

\begin{abstract}
In Egypt, an agro-industrial company, in association with a non-governmental organization, began setting up milk collection centres within producers' organizations in 2011 . The project was very active in the Beni Suef Governorate. This article analyses the milkshed evolution over the past 50 years and the project impact. Using interviews and historical data, a diachronic analysis was performed. The evolution can be divided into four phases: before 1980, dairy products were primarily sold on the local market; from 1980 to 2000, a "milkshed centred" development drove the dairy sector; from 2000 to 2011, the sector was driven by the demand in Greater Cairo; and since 2011, the arrival of the agro-industry has introduced new dynamics in local milk collection. Locally, the development of collection centres led to a rise in milk prices and improvements to milk hygienic quality. Demographic and dietary changes have stimulated demand for dairy products. Liquid milk collection has developed since the liberalization of public policies and improved infrastructure. The agro-industry is struggling to penetrate the highly competitive local milk collection sector and the model's future is uncertain.
\end{abstract}

Keywords: milk collection / regional development / family farms / dairy industry / Egypt

Résumé - Évolution d'un bassin laitier et rôle des centres de collecte de lait alternatifs en Égypte. En Égypte, depuis 2011, une entreprise agro-industrielle, avec l'aide d'une organisation non-gouvernementale, implante des centres de collecte de lait au sein d'organisations de producteurs. Ce projet a été très actif dans le gouvernorat de Beni Suef. Cet article analyse les évolutions du bassin laitier au cours des 50 dernières années et les influences du projet. À l'aide d'entretiens et de données historiques, une analyse diachronique a été conduite. Quatre séquences se dégagent de cette évolution. Avant 1980, le commerce de produits laitiers sur le marché local dominait ; de 1980 à 2000, un développement « bassin centré » du secteur laitier a eu lieu ; de 2000 à 2011, la demande du Grand Caire a stimulé le secteur ; et depuis 2011, l'entrée de l'agro-industrie dans la collecte locale a introduit de nouvelles dynamiques. Localement, les centres de collecte ont permis une revalorisation des prix du lait et une amélioration de sa qualité sanitaire. Les évolutions démographiques et des régimes alimentaires ont stimulé les demandes en produits laitiers. La libéralisation des politiques publiques et l'amélioration des infrastructures ont favorisé l'essor de la collecte de lait liquide. L'agro-industrie semble avoir du mal à s'insérer dans la collecte du lait de Beni Suef, fortement concurrentielle, et l'avenir du modèle promu est incertain.

Mots clés : collecte du lait / développement régional / exploitation agricole familiale / industrie laitière / Égypte

\section{Introduction}

Demographic and dietary changes, including greater consumption of animal products, have led to an increase in

\footnotetext{
* Corresponding author: annabelle.daburon@cirad.fr
}

demand for dairy products in all continents. A few major private agro-industries are competing for shares in the new markets, which are often in developing countries and involve the use of dried milk, from the global market and locally produced fresh milk. Dairy mega-farms are being developed, but companies are increasingly in contact with family farms as a sourcing strategy (Nestlé Milk District Model, Danone 


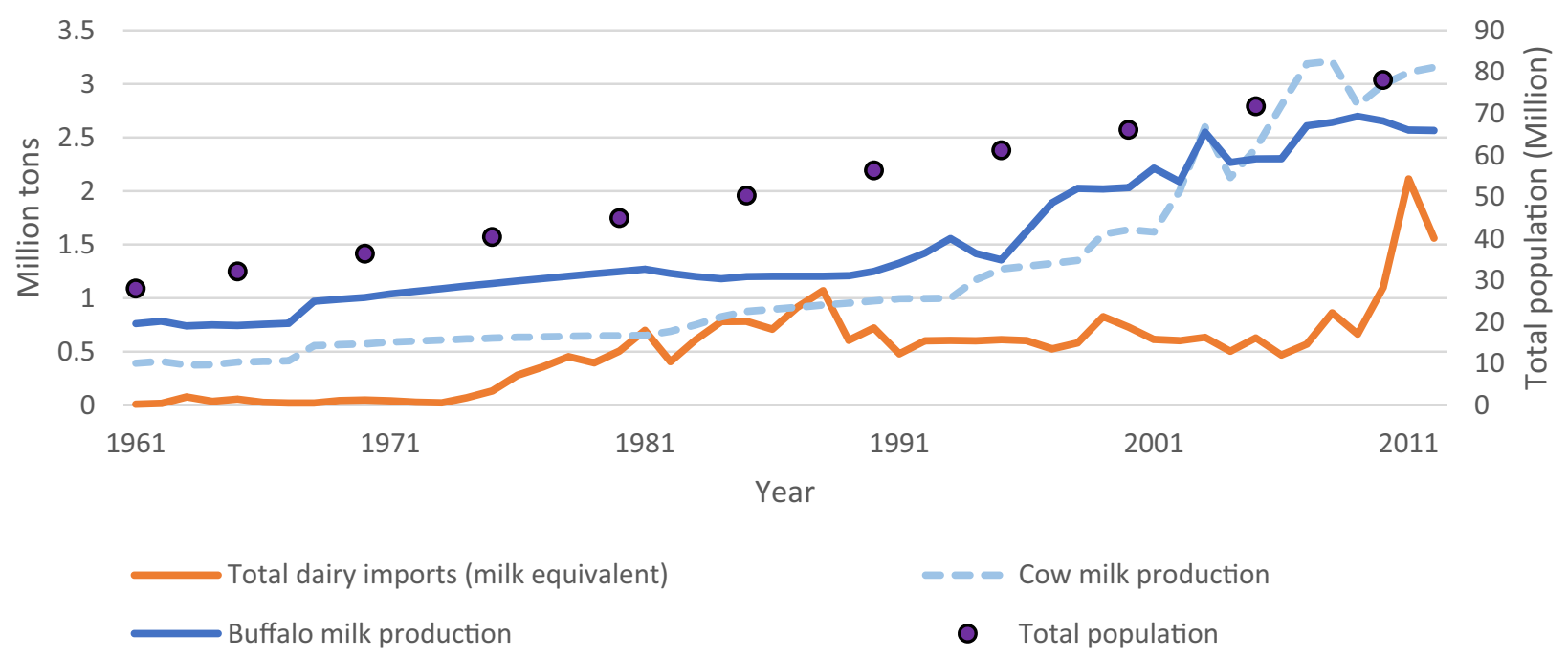

Fig. 1. National dairy production and imports in relation to demographic growth in Egypt from 1961 to 2012.

Fig. 1. Production, importations laitières et croissance démographique en Égypte de 1961 à 2012.

Ecosystem initiatives, etc.), promoting inclusive businesses (Kelly et al., 2016). Milk-sourcing projects are often associated with non-governmental organizations (NGO) (Gold et al., 2013). By providing agricultural services to producers' community, companies and NGOs seek to improve the quality and quantity of the raw material collected to meet agroindustrial standards. These projects carry development opportunities and risks. Understanding the general context where they operate appears essential to ensure their sustainability (Vatin, 2008). Egypt faces tough challenges. Its population has more than quadrupled in 60 years (92 million in 2015). Urban encroachment threatens arable land availability and water resource is scarce. Most milk is produced by family farms, with a peak production in winter. Large and mega dairy farms breeding thousands of cows complete the national production. Yet, Egypt has to import 2 million tons of milk equivalent, increasing the national trade deficit (Fig. 1). In this context, an agro-industrial enterprise has been promoting milk collection centres (MCC) since 2011; an NGO is responsible for developing MCCs within pre-existing farmers organizations supervised by public employees. The project's aim was to collect cow milk from family farms to supply a yogurt processing plant in Greater Cairo and to encourage local development in the regions hosting the MCCs. It has been very active in the Beni Suef (BS) Governorate since 2011 and claimed its key role in milk market development.

This paper explores the role of the agro-industry milksourcing project in the evolution of the dairy sector of the BS milkshed. Did the project initiate the creation of a local milk market? Our hypothesis is that MCCs: (i) arrived in an already highly competitive market; (ii) modified milk prices in favour of small suppliers (farmers and milk collectors) and achieved lasting improvements to dairy hygiene.

\section{Material and Methods}

Project promoters intensively invested in the Nile Valley of BS Governorate justifying our choice of investigating the milkshed of this area. The BS milkshed surrounds the city of
Beni Suef (120 km south of Cairo) (Fig. 2) and follows the Nile Valley borders (excluding desert land and Fayoum Oasis in the west). A literature review helped us to identify relevant data on the BS region: history, demographic trends and changing demands.

An in-itinere socio-economic impact study of the project has been conducted during three years (2014-2016) at farms, community and supply chain level. In BS, three villages were selected according to their involvement with the project in 2014 (had an MCC, will receive an MCC and no link with the project). A total of 76 farmers were interviewed, selected according to their milk marketing practices (dealing with MCC or not). 11 dairy collectors and $4 \mathrm{MCC}$ of these villages were also interviewed. They all received a visit every year. Semi-structured interviews were performed to collect data on socio-economic and technical characteristics of these diverse systems. Historical qualitative data were also collected on their dairy activity and the milkshed recent evolution. It will be the main material for this analysis. Participatory meetings were also held in the village with the longest involvement of the project to assess the dairy sector evolution after the MCC opening, including milk hygienic quality evolution. It gathered diverse dairy stakeholders of the village: a milk collector, 2 farmers, a feed trader, 2 MCC employees, a veterinary, an animal trader, and 2 cooperative employees. Additional data were collected via open discussions with key figures involved in the local dairy sector and in the project. Our analysis is consistent with a realistic narrative approach (Vaara et al., 2016). By combining these diverse sources, we tried to rebuild the recent evolution of BS milkshed.

\section{Results}

The evolution of BS milkshed is depicted in Figure 3 and will be detailed in the following paragraphs.

\subsection{Before 1980: dairy products marketed on the local market}

In 1947, the governorate's population was 600,000 (Shousha, 1947) (Fig. 4). Its economy was based on 


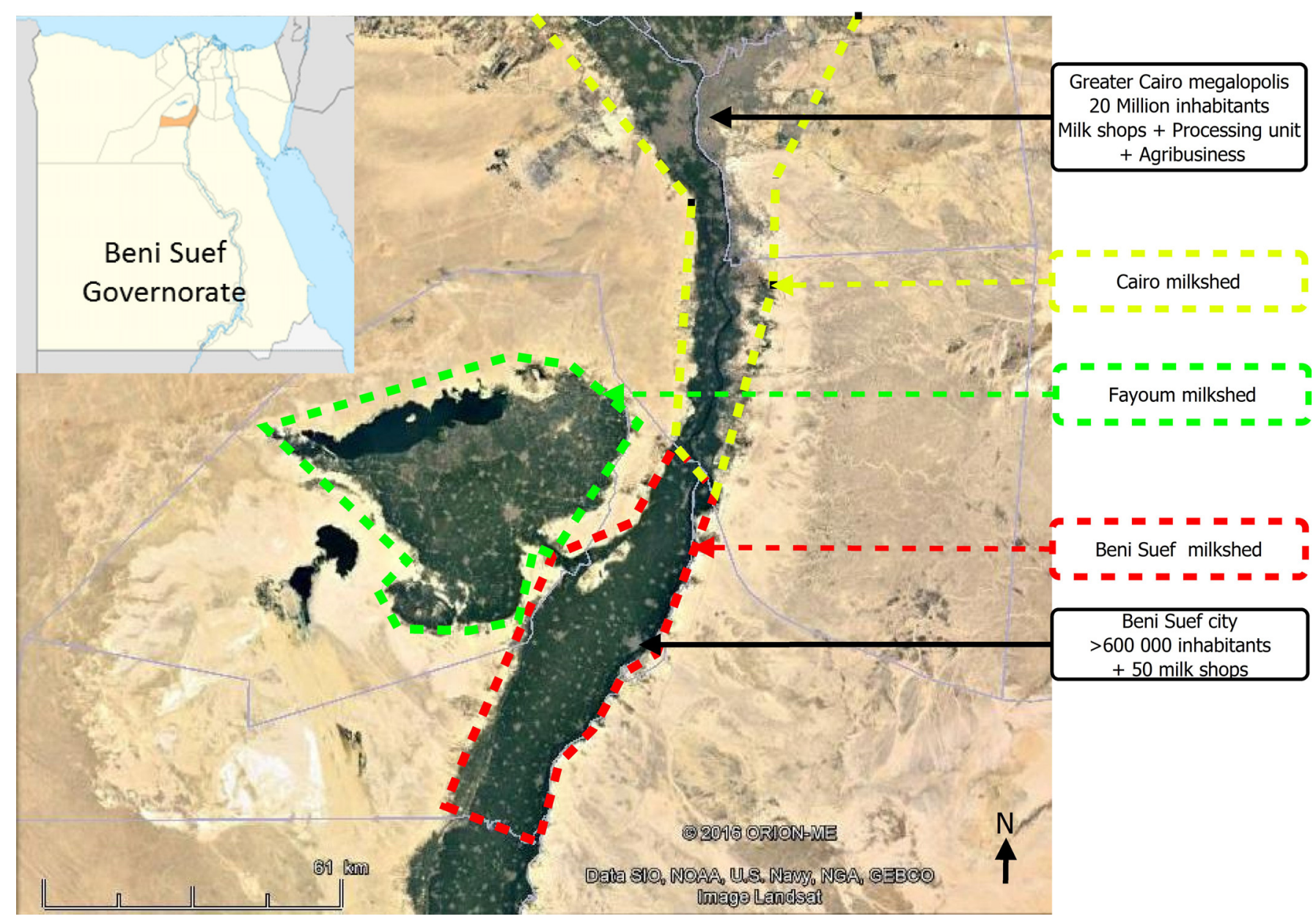

Fig. 2. Beni Suef Governorate and the limit of the milkshed in 2015 .

Fig. 2. Gouvernorat de Beni Suef et périmètre du bassin laitier considéré en 2015.

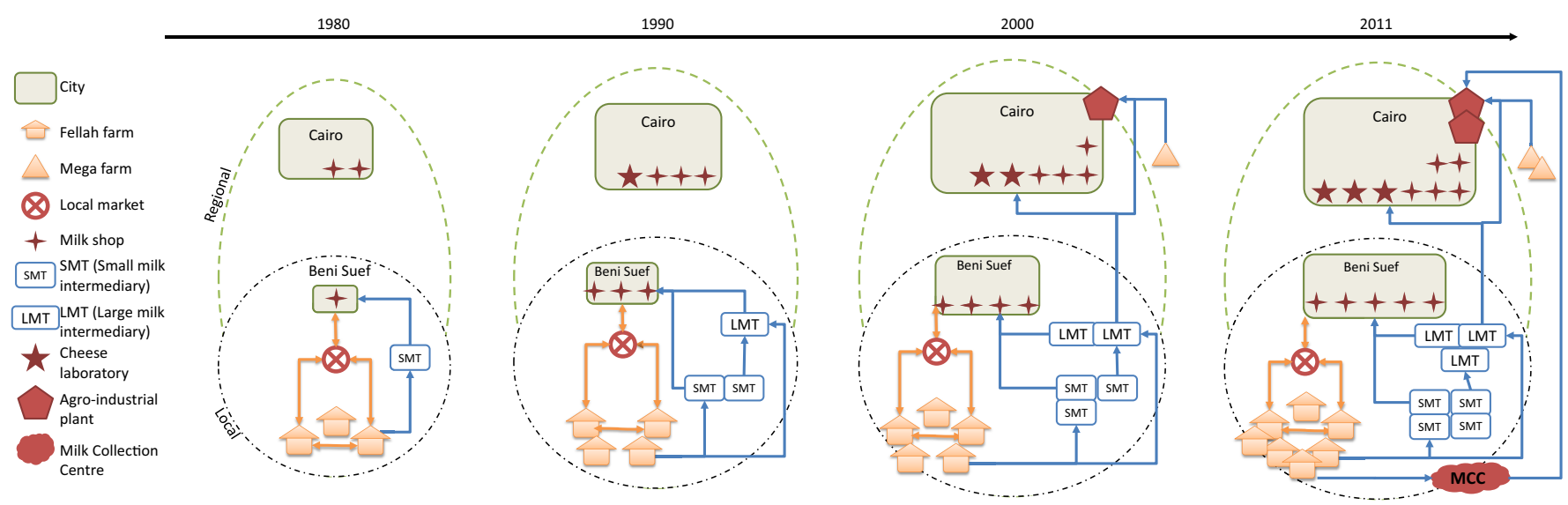

Fig. 3. Beni Suef milkshed chronicle.

Fig. 3. Chronique du bassin laitier de Beni Suef.

agriculture. BS city was linked to Cairo, but the infrastructure was poor. The majority of the city population were rural migrants, who maintained a rural lifestyle (Ibrahim and Ibrahim, 2003). The demographic evolution led to an increase in local demand for homemade processed dairy products, as well as for cow and buffalo milk (Galal, 2002). The largest rural population was and remains "Fellahin", peasant working in small family farms. They combined integrated crop and livestock production (Ayrout and Williams, 2005) on less than 1 ha. Agriculture was subject to State planning and farmers had to plant important areas with cotton. Cereals (maize and wheat), vegetables (tomatoes, onions, etc.) and green fodder (berseem, 


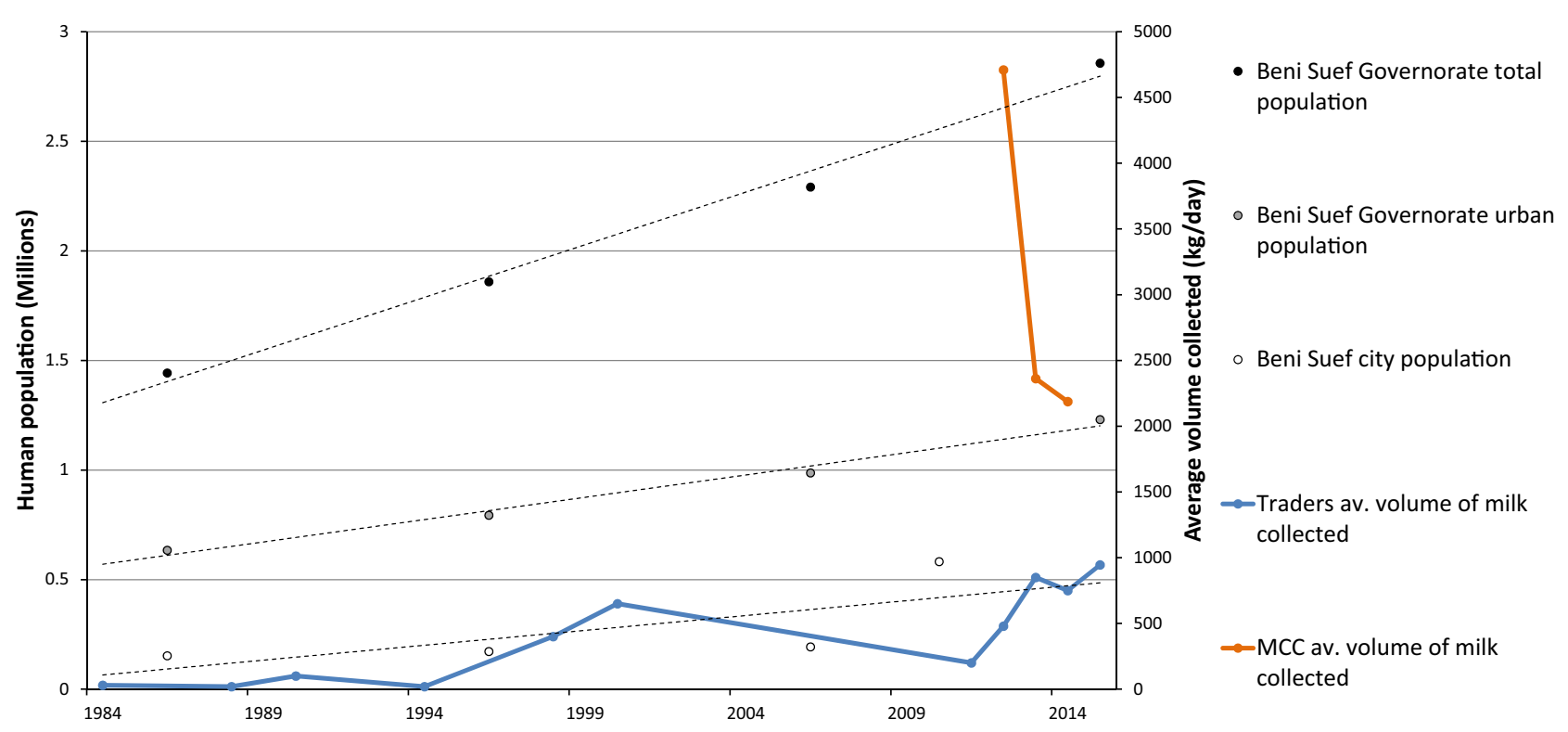

Fig. 4. Beni Suef population evolution and average milk volumes collected by MCCs and milk traders.

Fig. 4. Évolution de la population de Beni Suef et moyennes des volumes de lait collecté par les MCC et les collecteurs de lait indépendants.

maize fodder) were also grown (Ibrahim and Ibrahim, 2003). Small herds were kept (one or two cows, one buffalo and a few sheep or goats). Calves were fed on milk. Women used the surplus to make butter or cheese (Karish or Mesh) for home consumption or sale (neighbours or local markets). Buffalo butter or cheese was particularly appreciated. Although several larger farms existed, dairy speculation was absent in the $70 \mathrm{~s}$. Product quality was tested using organoleptic analysis. At that time, the fluid milk market was limited as selling milk was considered a sign of poverty.

\subsection{0-2000: a "milkshed centred" development in the dairy sector}

During the 1980s, the population increased throughout the BS Governorate and in BS city. Major developments, including the construction of a bridge across the Nile, a highway to Cairo, an extension to BS University and the creation of a new city on the east bank of the Nile (New BS) stimulated local economy. Urban encroachment on arable land and population growth increased farm fragmentation. Between 1980 and 1990, the total number of farmers increased by $12.9 \%$ (Ayeb, 2010), mainly among small farms ( $<1 \mathrm{ha}$ ) (Robson et al., 2012) in Egypt. Urban growth and dietary changes increased local demand for dairy products. Several farmers from Zarabi, a village $3 \mathrm{~km}$ from BS city, began collecting small volumes of cow milk $(<50 \mathrm{~kg} /$ day $)$ in a perimeter of less than 2 to $3 \mathrm{~km}$. The daily round was made on a donkey or bicycle. Milk was sold to cafés in downtown BS. Initially, milk collection provided a supplementary income for farmers. By the end of the $80 \mathrm{~s}$, they became milk collectors, gathering $100-200 \mathrm{~kg} / \mathrm{day}$ of cow milk, with a farm activity on the side. The arrival of cheap equipment from Asia (motorbikes, tricycles) meant they could extend the collection perimeter (up to $5 \mathrm{~km}$ ). Subsequently, several milk collectors began renting premises in downtown BS to sell directly to consumers. In the mid-nineties, Zarabi became a dairy cluster in the governorate: 20 families collected 0.5 to $1 \mathrm{t} /$ day of milk from farmers and employed two or three family members. Milk was sold to creameries and a few families started processing milk, using traditional techniques. At the same time, agro-industrial products appeared on the local market in direct competition with artisanal products. Gradually, the taboo regarding liquid milk marketing disappeared, so women could supplement family incomes by selling fresh milk sparing processing time. With the liberalization of the agricultural sector, farmers had more freedom to choose their cropping pattern and increased fodder and dairy production. Taking advantage of the city's proximity, they relied on intermediaries to sell their milk on the urban market. Until then, dairy quality was subject to organoleptic controls. The number of both cows and buffalos increased during this period at the national level. Holstein genetic spread through artificial insemination and resulted in important local genetic losses. Private industrial dairies multiplied in the country encouraged by authorities while informal sector remained neglected.

\subsection{0 to 2011: structuration and emergence of major local operators}

In the $90 \mathrm{~s}$, demographic trajectories continued their upward trend: in 2003, the population in Greater Cairo reached 15 million. Dairy products consumption and liquid milk demand increased as well (EMHP, 2012). The number of dairies using industrial processes increased in the megalopolis. They produced Roumi (hard cheese similar to Parmesan), White cheeses (fetatype cheeses), Mozzarella, yogurt, etc., collecting several tons of whole and/or skimmed milk, completed with dried milk, on a daily basis. Simultaneously, giant agribusinesses were developing their activity in and around Cairo. In addition to milk powder, their milk supply was guaranteed by their own mega-farms (thousands of dairy cattle) in the New Reclaimed Land (desert land developed for farming through national policies initiated in the 50's and continuing nowadays) and by collecting from 


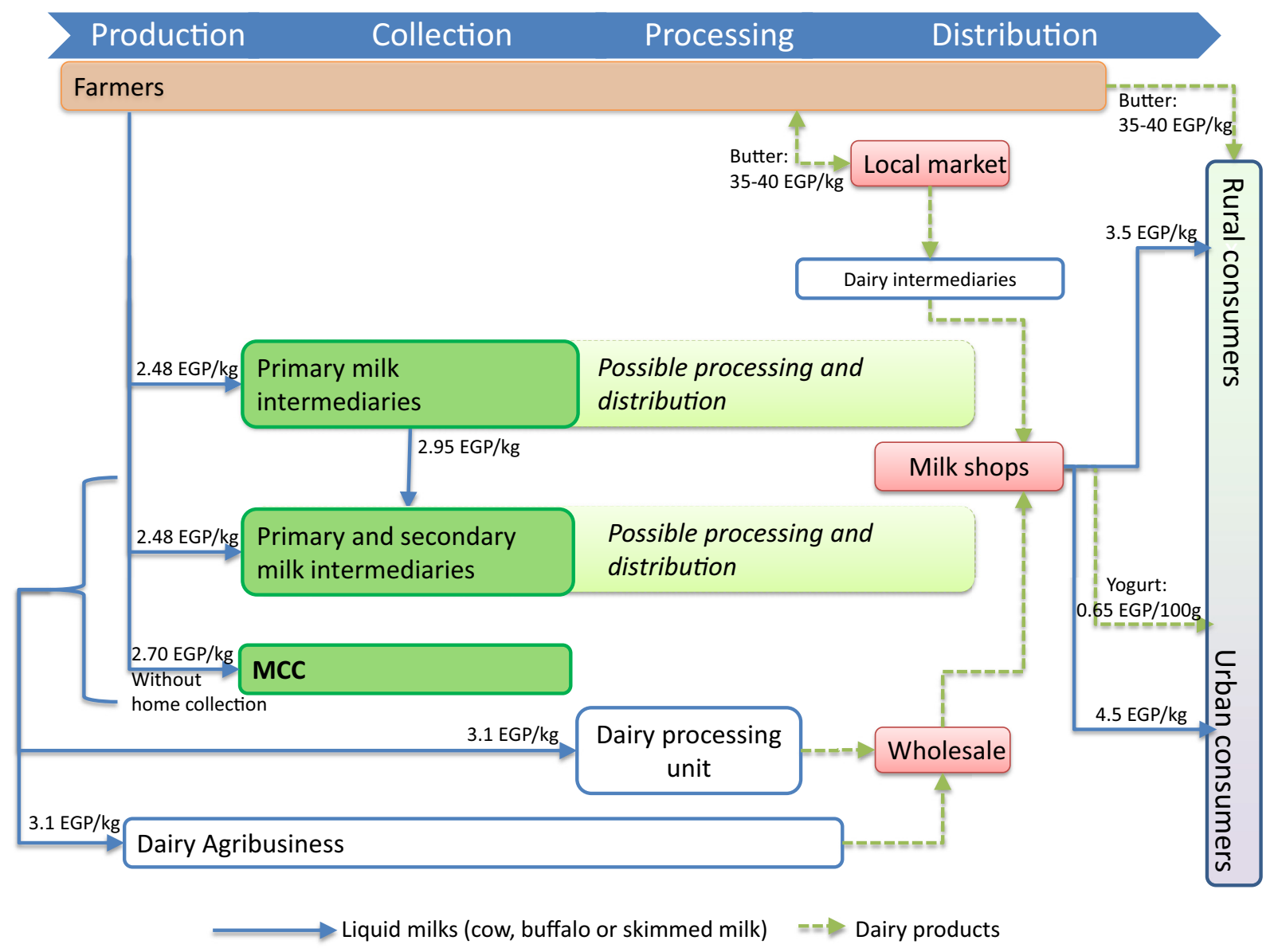

Fig. 5. Beni Suef contemporary supply chain. Average prices are in Egyptian pounds and for cow milk in winter 2015 when no other product is specified.

Fig. 5. Filière laitière contemporaine de Beni Suef. S'il n'y a pas de précision, les prix moyens indiqués sont ceux du lait de vache pendant l'hiver 2015.

private industrial farms or milk collectors. Although the demand trends provided new opportunities for regional collectors, industrial processes imposed new milk quality standards. In BS, most milk collectors continued to collect from fellahin and sold their products to consumers in milk shops on an increasingly competitive urban market. Few milk collectors' families invested in equipment (coolers, large tanks, pick-ups) to reach Cairo's market. Five larger operators emerged in the BS milkshed, centralizing 1-5 t/day of cow milk (raw and skimmed), collected from farmers and small local milk collectors. It allowed for few speculative dairy farms to appear (20-50 cows, with up to $20 \mathrm{ha}$ ) in the governorate. In 2010, milk intermediaries paid 1.5 EGP (Egyptian Pound)/kg (in January 2015, 1 euro equalled 8.57 EGP) for cow milk at the farm gate and sold to urban consumers at $2.2 \mathrm{EGP} / \mathrm{kg}$. With the new industrial quality requirements, large milk traders had to start to use electronic devices to test milk quality.

\subsection{After 2011: agro-industry competing on the local milk market}

The agro-industry entered the milk collection market in the BS milkshed in 2011, while demographic and urbanization trends continued (Fig. 4). Since then, several marketing channels in the region have been co-existing to add value to milk off-farm (Fig. 5 shows average milk prices and volume for winter 2015):

- The traditional local market: women sell their dairy products to neighbours or on the local market. Butter (buffalo milk) was sold to consumers for 35-40 EGP $/ \mathrm{kg}$.

- The skimmed milk channel: some women own a milk separator (centrifugal device that separates milk into cream and skimmed milk), which they can rent to other woman in the village (average of $3 \mathrm{EGP} / \mathrm{animal} /$ week). These milkprocessing houses also give women the opportunity to socialize. After skimming, customers bring back cream and skimmed milk for home processing. Skimmed milk was collected for 1.10-1.20 EGP/kg by dedicated milk collectors.

- The whole milk channel (mainly cow milk in BS): small intermediaries collect two times a day, $100-200 \mathrm{~kg} /$ day from farms in all the villages in the governorate, using a tricycle and no cooling system (2.48 EGP/kg at farm gate). They can sell some milk to rural consumers $(3.5 \mathrm{EGP} / \mathrm{kg})$ during their round or to bigger milk collectors (2.95 EGP/ $\mathrm{kg}$ ) as well as MCC. Most of the larger milk collectors are from Zarabi, a village that has become a dairy cluster with a regional influence. Its members channel most of the milk 
from the milkshed to the city of BS city and the Cairo area. Almost 40 families collect 0.5-2.0 t/day of milk (mainly cow milk) from BS farms (2.48 EGP/kg at farm gate) and other milk collectors. Processing remains a marginal activity for these families. Buffalo milk collection is uncommon in the BS milkshed. It is primarily supplied by milk collectors from the Fayoum milkshed (4.15 EGP $/ \mathrm{kg}$ ). It was sold at $6 \mathrm{EGP} / \mathrm{kg}$ to consumers in BS city. In priority, BS milk collectors market their products in their milk shop in BS city (an estimated total of 50 shops). Cow milk was sold at $4.5 \mathrm{EGP} / \mathrm{kg}$ and yogurt at $0.65 \mathrm{P} / 100 \mathrm{~g}$. Surplus is sold to one of the five major collectors in the area connected with agro-industries and cheese laboratories in Cairo $(2.95 \mathrm{GP} / \mathrm{kg})$ or to MCC $(2.70 \mathrm{GP} / \mathrm{kg})$. The five large collectors test their supply of milk for fat and protein content introducing quality bonuses and penalties. However, the rest of the chain lacks the equipment to test for quality. Almost all milk collectors provide financial services (credit and loans) to their suppliers. Thus they play a key role in agricultural activity and maintain longterm relationship with their suppliers and outlets without formal contracts.

- MCC channel: since 2011, MCCs have opened. The main terms of the contract between the agro-industry and agricultural association receiving a new MCC include: the delivery of all the milk collected for a period of 5 years in exchange for the MCC's equipment, agricultural services for suppliers during the initial phase of development (training courses, veterinary services, feed, etc.) focused on woman empowerment, management support and advantageous milk prices when the MCC first opened. The business model is designed to maintain agricultural services by using some of the proceeds from milk sales. The MCC accepts any quantity of milk from its suppliers. Alcohol tests are performed occasionally. Milk composition (and rarely presence of antibiotic residue) is analysed when large quantities of milk are supplied and before each delivery to the plant in the outskirts of Cairo (150-200 km away depending on the MCCs' location). Sales are concluded when the milk delivered meets the company's requirements (quality and quantity). Milk failing to meet requirements is rejected. MCC then have to find alternative marketing channels without bargaining power. When it opened, the MCC was very attractive to farmers and local milk collectors. Its direct link with a major multinational company suggested increased security and new perspectives. In 2012, this company offered an average of $2.70 \mathrm{GP} /$ $\mathrm{kg}$ to MCC. The recommended margin was set at $0.25-0.30$ EGP. Thus, the estimated MCC price was $2.40 \mathrm{GP} / \mathrm{kg}$ for suppliers (farmers and milk collectors) compared to milk collectors who paid $1.5 \mathrm{EGP} / \mathrm{kg}$ the previous year. In 2012, MCC received an average of $4 \mathrm{t} /$ day. Local milk intermediaries resisted by increasing their prices. Thus, milk prices for farmers increased and the volume collected by MCC decreased. In 2014, the average volume collected decreased from $4 \mathrm{t} /$ day to $2.5 \mathrm{t} /$ day as five MCCs collected milk regularly in the BS area. MCC offered an average price of $2.70 \mathrm{EGP} / \mathrm{kg}$ in the winter of 2015 . The conventional milk collectors offered lower prices $(2.48 \mathrm{EGP} / \mathrm{kg})$, but had lower quality requirements and collected at home.
Milk hygienic quality evolution in the village was assessed during participatory meetings. According to this group, by introducing new milk quality requirements and offering courses, the MCC helped farmers improving their production practices. Based on their perception, the milk hygienic quality improvement was scored to $30 \%$ in the village. Families adjusted their practices to benefit from the MCC's high initial prices. Regardless their marketing channels, they kept the new practices to protect their families' health. The standards enforced by independent traders also contributed to this evolution. However, the company regularly rejected MCC milk for quality reasons. Subsequently, milk was sold to other businesses below cost price, which undermined the MCC's economic balance. Consequently, when the company stopped providing financial support, the MCC found it difficult to maintain agricultural services for farmers. Over the years, the MCC collected smaller quantities (Fig. 5).

\section{Discussion-Conclusion}

Demographic growth and diets evolution led to an increase in the demand for dairy products. It also generated the bottomup structuration of the Beni Suef (BS) dairy sector, which was made possible by more liberal policies and improved infrastructure. The evolution of the BS milkshed until the $90 \mathrm{~s}$ is comparable to the Brasil Novo milkshed, in Brazil (Poccard-Chapuis and Carvalho, 2015) where local urban demand and know-how facilitated the organization of the dairy sector within the milkshed. This evolution has not been observed in Ethiopia, where the increasing urban demand did not lead to the local dairy sector structuration (Geleti et al., 2014). After the 90's, the opening up of the BS milkshed strengthened the dairy sector structuration. Few operators were able to reach the demands of cheese-processing units and agroindustrial in Greater Cairo. Meanwhile industrial dairy products entered BS market. This validates the first hypothesis: a dynamic dairy activity had developed in the BS milkshed before the agro-industry began to collect milk locally.

In 2011, when milk collection centers (MCC) arrived, a new sequence started. Similar to the cases in Turkey, MCCs could be conceived as proximity operators that stimulated the dairy network locally and created a new "bridge" between producers and agribusiness (Sayin et al., 2011). The MCCs generated positive competition in BS. They stimulated a rise in milk prices and improved local milk quality. Farmers and small local collectors could diversify their marketing channels, increasing their resilience. Interesting research perspectives would be to consider the impact of this evolution on the access to dairy products for the poorest segment of the population which might have been hindered. Large traditional collectors were quick to respond to the new competition and the MCCs faced difficulties. Meeting the agro-industrial quality and quantity requirements regularly remains difficult for MCCs. It undermines their economic stability. As in the case of Morocco (Faysse and Simon, 2015), the MCCs' strategy to improve milk quality was limited to farmers delivering directly their milk (without intermediary). Encompassing all the actors of the local value chain in a management that would focus on both improving milk quality of MCC suppliers (farmers and milk intermediaries) and dealing with milk quality heterogeneity, by 
relying on the local value chain, might be a more efficient strategy.

This last sequence can be considered in the light of two cases from Senegal. In 1992, Nestlé tried to develop a local milk collection system. It faced problems similar to those seen in the model currently promoted in Egypt: high transport costs, milk quality issues and fairly unattractive prices offered by agro-industries compared to the local market. The company withdrew its activity after 10 years (Vatin, 2008). On the contrary, La Laiterie du Berger is a successful dairy in Senegal. Local milk collection and milk powder are processed into high quality value-added dairy products for urban consumers. An agro-industrial group has recently invested in the enterprise (Corniaux, 2015). La Laiterie $d u$ Berger raises the question of the possibility for a MCC to diversify sources of income by taking advantage of nearby urban markets while continuing to supply raw milk to the agro-industry. Diversifying MCCs activities by processing and diversifying marketing channels would help overcome the problem of milk heterogeneity and might improve financial stability. Gender dimension was a corner stone of the MCC project. It provided to woman employment, trainings and opportunity to market raw milk (reducing processing time). As in the Bengali case study, the role of women may have been strengthened by the MCCs projects (Quisumbing et al., 2013). Paradoxically, it also competed with traditional businesswomen (those with a separator or who sell cheeses in the market).

Several development pathways can be considered for the future development of the BS milkshed. Population growth and changing diets will continue to drive demand. It will create new market opportunities for businesses and agro-industries will continue to invest in their search for new milk sources. Fellahin are likely to remain the main milk producers in Egypt for years to come. They will continue to raise agro-industrial interest. The sustainability of the top-down models currently promoted is uncertain in the short term, given their precarious economic situation. As long as agro-industry enterprises do not offer incentives competing with the informal chain, attempts to secure their milk supply will remain precarious. In order to develop adapted business strategies, a deeper acknowledgement of the local contexts is essential. Adjusting these initiatives in a process of co-construction with local milk collectors seems to be a pathway to explore. MCC could benefit their social anchorage, as well as their knowledge of the region (Kelly et al., 2016). Diversifying marketing channels by relying partially on them is a key for MCC to deal with milk quality heterogeneity and thus become more profitable. Furthermore, in a context where consumer's expectations regarding quality are increasing and a new food law is under preparation, MCCs involvement towards diverse dairy actor's hygienic practices could constitute an added synergy between public decision makers, project managers and micro-enterprises from the informal market. More generally, competition for land use and water scarcity calls into question the future of agriculture and dairy sector in BS. The escalating cost of feed (fodder and concentrates) is already problematic for dairy production. If agro-industry plans to maintain its family farm supply, optimizing efficiency of local resources use and limiting tensions by promoting inclusive coordination mechanisms is a pathway. Interbranch organizations dedicated to build inclusive value chains, rather than integrated, could help to progress towards values creation benefiting both the investing company as well as the local stakeholders. Ultimately they could contribute to the advent of a more sustainable territory.

Acknowledgements. This study was conducted within the framework of project SIADEEP financed by Danone Ecosystem. We wish to thank the researchers from APRI and Cairo University who participated in the study, as well as the producers and intermediaries in the sector who kindly gave us their time.

\section{References}

Ayeb H. 2010. La crise de la société rurale en Egypte. La fin du Fellah ? Hommes et sociétés. Paris: Karthala.

Ayrout HH, Williams JA. 2005. The Egyptian peasant. Cairo; New York: American University in Cairo Press.

Corniaux C. 2015. Bassin laitier de la basse vallée du fleuve Sénégal (Sénégal). In: Napoléone M, Corniaux C, Leclerc B, eds. Voies Lactées. Dynamique des bassins laitiers entre globalisation et territorialisation. Avignon (France): Cardère.

EMHP (Egyptian Ministry Of Health And Population). 2012. Egypt Nutrition Landscape analysis report 2012. Cairo: Egyptian Ministry of health and population; Unicef. Available from https://www. unicef.org/mena/Landscape_Anaylsis_Report_January_2013(1).pdf

Faysse N, Simon C. 2015. Holding all the cards? Quality management by cooperatives in a moroccan dairy value chain. European Journal of Development Research 27(1): 140-155.

Galal OM. 2002. The nutrition transition in Egypt: obesity, undernutrition and the food consumption context. Public Health Nutrition 5(1): 141-148. doi: 10.1079/PHN2001286

Geleti D, Hailemariam M, Mengistu A, Tolera A. 2014. Analysis of fluid milk value chains at two peri-urban sites in western oromia, Ethiopia: Current status and suggestions on how they might evolve. Global Veterinaria 12(1): 104-120. doi: 10.5829/idosi.gv.2014.12.01.81164

Gold S, Hahn R, Seuring S. 2013. Sustainable supply chain management in "base of the pyramid" food projects - a path to triple bottom line approaches for multinationals? International Business Review 22(5): 784-799. doi: 10.1016/j.ibusrev.2012.12.006

Ibrahim FN, Ibrahim B. 2003. Egypt: An economic geography. London: I.B. Tauris.

Kelly S, Vergara N, Bammann H. 2016. Inclusive business models Guidelines for improving linkages between producer groups and buyer of agricultural produce. Rome: FAO, Available from http:// www.fao.org/3/a-i5068e.pdf

Poccard-Chapuis R, Carvalho S. 2015. Bassin laitier de Brasil Novo (Brésil). L'émergence d'un bassin laitier localisé sur un front pionnier. In: Napoléone M, Corniaux C, Leclerc B, eds. Voies Lactées. Dynamique des bassins laitiers entre globalisation et territorialisation. Avignon (France): Cardère.

Quisumbing AR, Roy S, Njuki J, Tanvin K, Waithanji E. 2013. Can dairy value-chain projects change gender norms in rural Bangladesh? Impacts on assets, gender norms. Washington: IFPRI Available from http://ebrary.ifpri.org/utils/getfile/collection/ p15738coll2/id/127982/filename/128193.pdf

Robson JS, Ayad HM, Wasfi RA, El-Geneidy AM. 2012. Spatial disintegration and arable land security in Egypt: A study of smalland moderate-sized urban areas. Habitat International 36(2): 253-260. doi: 10.1016/j.habitatint.2011.10.001

Sayin C, Mencet MN, Karaman S. 2011. The roles of milk collection centers in milk distribution channels in turkey: A case study of 
Antalya. African Journal of Agricultural Research 6(1): 174-180. doi: 10.5897/AJ AR09. 789

Shousha AT. 1949. Cholera epidemic in egypt (1947): A preliminary report. Bulletin World Health Organization 1(2): 353-381.

Vaara E, Sonenshein S, Boje D. 2016. Narratives as Sources of Stability and Change in Organizations: Approaches and Directions for Future Research. The Academy of Management Annals 10(1): 495-560. doi: 10.1080/19416520.2016.1120963

Vatin F. 2008. Le lait et le marché. Comparaison dans l'espace et dans le temps. In : Travaux et documents de l'ATP Icare 1. Montpellier: CIRAD. Available from http://epe.cirad.fr/fr2/icare/docs/Icare WP_comm_1_Vatin_VF.pdf

Cite this article as: Daburon A, Radwan M, Alary V, Ali A, Abdelghany S, Fouad K. 2016. Evolution of a milkshed and role of alternative milk collection centres in Egypt. Cah. Agric. 25: 65008. 